\title{
France urged to open up élite education ...
}

[PARIS] France's élite grandes écoles should operate less in isolation from the rest of higher education and be integrated more into the university system through the creation of joint courses and degrees and the sharing of facilities such as libraries and laboratories.

This is the main recommendation of the report 'For a European Model of Higher Education' commissioned by Claude Allègre, the minister for national education, research and technology, from a 17-member panel that included Georges Charpak, who won the 1992 Nobel prize for physics, and the geneticist Axel Kahn.

The panel, chaired by Jacques Attali, who used to be adviser to the former president François Mitterrand and is himself a product of the grandes écoles, also included leading industrialists Pascal Brandys (chief executive officer of the biotechnology company Genset), Francis Mer (head of Usinor) and Jérome Monod (head of Lyonnaise des Eaux-Suez).

The 200 or so grandes écoles - the best known of which are the Ecole Polytechnique, Ecole des Mines, Ecole des Ponts et Chaussées and Ecole Normale Supérieure - were set up in the eighteenth century primarily to supply top-flight engineers and scientists to the senior civil service. But their raison d'être is becoming increasingly obsolete, according to the report, given the decreasing role of the state in industry and the economy.

Graduates of the écoles have served France well in the past within the state's massive technological programmes in such fields as nuclear energy, aerospace and high-speed trains. But economic needs have now shifted towards a higher education system that fosters contacts between scientists, entrepreneurs and small companies.

The report argues that greater integration of the grandes écoles into the university landscape is necessary to achieve this goal and to produce highly qualified graduates for the private sector.

One of the main weaknesses of the grandes écoles is in scientific research. Their courses do not provide for study and research towards doctorates, and the main centres of research are not in the grandesécoles but in the universities. Allègre consistently points out that this has resulted in France's senior civil servants often lacking a culture of research and science-based innovation.

To help remedy this situation, the report recommends the creation of a joint campus or 'poles' between neighbouring universities and grandes écoles, with students having access to courses in both - or being registered for joint degrees — while sharing libraries and other facilities.

\section{... but university reform ideas meet resistance}

[PARIS] Although the Attali report's recommendations for reform of the élite grandes écoles have been widely welcomed (see above), the fate of proposals for significant changes in the university system is uncertain. Past efforts ended ignominiously after protests by students and staff.

The report implicitly endorses the wish of the national education minister, Claude Allègre, to create competitive research-based universities. At present, universities are centrally organized, officially uniform in quality and offer national degrees.

The report recommends creating a national evaluation committee to rank individual university departments on research and teaching, and that more funding be awarded to the strongest. It also proposes increasing institutions' autonomy by boosting the power of vicechancellors and transferring buildings and land from the state.

At the same time, the report advocates making universities more accountable to economic and local needs through governing boards made up of local representatives and industrialists, to sit alongside the university board. In particular, governing boards could make nominations for vice-chancellor and participate in the election.

Both the conference of university vice-chancellors (CPU) and the unions are sceptical about this proposal. Unions argue that the current system, where the university president is elected by staff and students, is democratic and that outside interference would introduce economic interests at odds with universities' role in teaching and fundamental research. Bernard Saint-Girons, head of the CPU, describes the proposal as "unsatisfactory".

More broadly, proposals to increase competition are likely to be extremely controversial. Many in France, and in particular unions representing university staff and students, remain strongly attached to a national university system with open access.

Claude Lécaille, national secretary of SNESup, the main university teachers' union, describes the report's proposals as an "unacceptable" slippery slope to differential course fees and restricted access.

The education ministry last week declined to comment on the report's recommendations, although Allègre is reported to be pleased.

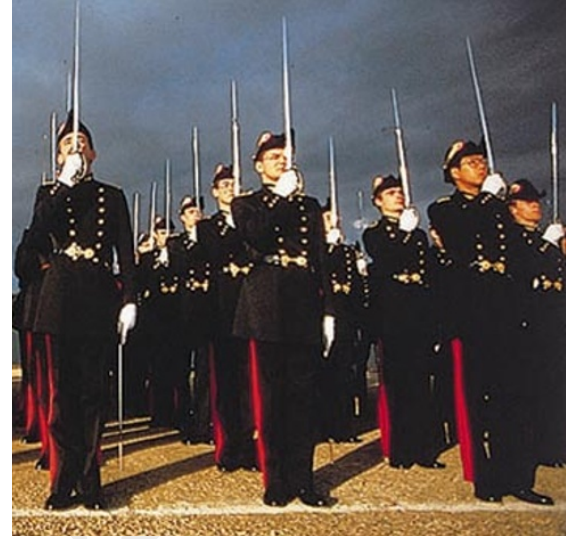

Storm clouds gather: grandes écoles such as the Ecole Polytechnique may face changes.

The report recommends ending the monopoly enjoyed by the grandes écoles on recruitment to the state's scientific and technical corps, with posts in the senior civil service being opened up to university graduates for the first time. It also proposes that selection for entry to the grandes écoles should be diversified to allow a greater representation of social classes and to increase the proportion of students with a science education.

At present, the best school-leavers undergo a special year of training for the entry competitions to the grandes écoles, while the rest who have passed the baccalauréat go to university. The excellent facilities enjoyed by students at the écoles contrast sharply with the dilapidated and overcrowded conditions at many universities.

The report argues that the selection process has become too élitist, benefiting almost exclusively the children of top civil servants or wealthy industrialists, who have enjoyed a privileged education. This social inequality has widened in recent decades, according to the report, with most entrants to the grandes écoles now coming from just a handful of top schools.

To counterbalance this trend, the report recommends that students at universities and technical colleges, and not just schoolleavers, should be allowed to apply to transfer to the grandes écoles. It also recommends that quotas should be fixed to guarantee an input of biologists and other science students.

The report's recommendations have been widely welcomed by university vicechancellors and unions representing university students and staff. Etienne Gouyon, director of Ecole Normale Supérieure and himself a former university lecturer, also says he is "broadly favourable" to the report.

But he is concerned that opening up recruitment to the grandes écoles to universities might result in one-way traffic, depriving universities of their best students and impoverishing them further.

Declan Butler 